\title{
Testimony and the Affirmation of Memory in Kazuo Ishiguro's Never Let Me Go
}

Yugin Teo

\begin{abstract}
In the alternative world of Kazuo Ishiguro’s Never Let Me Go, Kathy, Ruth and Tommy must find ways to hang on to the precious memories of their childhood. The affirmation of shared memories of Hailsham unites them, and the collective memories of the clones serve as testimonies to their plight in servitude to humankind. This examination of the novel provides a glimpse into Ishiguro's profound and elegiac work of memory.
\end{abstract}

Keywords: Ishiguro, memory, testimony, Ricoeur, holocaust 
The publishing of Never Let Me Go in 2005 heralded a temporary abandonment of a more experimental style of writing exhibited earlier in The Unconsoled and When We Were Orphans. Never Let Me Go bears closer resemblance to The Remains of the Day in its consistent tone of narrative voice and its slower narrative pace. The novel sees Ishiguro returning to a more deftly controlled and realist writing style, where he creates a tighter, more structurally compact, and (on the surface) less experimental piece of writing. Never Let Me Go, which in many ways is one of Ishiguro’s most affecting novels, depicts the complex relationship between Kathy, Ruth, and Tommy, and their relationship with the wider world around them and explores the hidden depths of humanity and the nature of human relationships. Memory is among the most important of themes that form the basis for Ishiguro's novels. The theme of memory pervades his novels, and has proved to be a hallmark of his writing and a theme that he constantly returns to examine in his work. This theme is apparent when examining the lives of these three friends and their relationship with Hailsham, their former school, thereby bringing into sharp focus the subject of community.

As he does in When We Were Orphans, Ishiguro demonstrates his continuing interest in the human desire for meaning in life. Mirroring his depiction of the plight of orphans in the earlier novel, Never Let Me Go depicts the lives of three clones who have no biological parents and who seek to fulfill the missions they set out for themselves. They have been excluded from society through an act of national forgetting and are left to forever live their lives in the shadows and drive along the “dark byways of the country” (Never Let Me Go 249) until they perform the ultimate sacrifice by giving up their bodies for the harvesting of organs. Kathy is thirty-one, 
“old” by clone standards, but nevertheless young by our human standards. Her recollections do not come with the same kind of weight of experience and time as the recollections of Masuji Ono or Stevens from Ishiguro's earlier novels An Artist of the Floating World and The Remains of the Day. Those earlier protagonists use memory as a tool to reorganize their thoughts in anticipation of a crucial forthcoming event. Kathy's recollections serve more as a tribute to her life, the lives of her school friends Ruth and Tommy, and the friendship they shared together. Kathy's return to the past, therefore, is not motivated by a deep sense of guilt or something that has gone wrong in the past; it is instead triggered by a wistful and carefree memory. That is not to say, however, that Kathy, Ruth, and Tommy do not harbor any regrets or guilt regarding their friendship over the years from their time at Hailsham.

\section{Collective Memories: the Clones and the Public}

There are two opposing forces at work in the novel: one is the desire of the nation to deny the existence of the clones, and the other is the clones' desire to cling to their memories; one is a desire to forget, the other a desire to remember. Following on from the Second World War in this alternative history of England, clones were reared in appalling conditions solely for the purposes of medical science, ${ }^{1}$ and it was only the creation of institutions such as Hailsham and a few others like it that brought ethical questions about cloning to the fore. These institutions tried to demonstrate that when the clones were reared in humane and cultivated environments they could "grow to be as sensitive and intelligent as any ordinary human being” (239). The school encouraged the students to produce their own works of art, and then exhibited these works to influential people around the country, insisting that the clones were in all 
aspects fully human. Enduring various scandals and incidents over time, public support for these movements waned and dissipated, bringing the national political and social climate back to what it was before these schools came about. People once again abhorred the existence of the clones, yet recognizing them as a necessary evil in order that their lives might be prolonged.

In the context of the novel, there is a sense that England's landscape is haunted by the ghosts of the clones who have been harvested for their organs. This sense of emptiness evokes an atmosphere similarly experienced in Night and Fog, Alain Resnais' compelling documentary about the Holocaust. There, the narrator's words that accompany a color visual montage of the ruins of the concentration camps convey a chilling emptiness that similarly surrounds the English landscape in Never Let Me Go:

As I talk to you, cold marsh waters fill the ditches As cold and sluggish as our memories ...

Nine million dead haunt this scene (Night and Fog)

The absence of those lives that have been eviscerated constitutes a deafening silence. The desire of the perpetrators to forget their crimes runs counter to the very nature of forgetting. In discussing the issue of amnesty applied to the arena of national memory, Susan Rubin Suleiman brings our attention to the ethical problem of the "injunction to forget.” Suleiman argues that an injunction to forget a crime "becomes absurd as well as reprehensible when it is uttered by - or on behalf of - the perpetrator" (225). Suleiman is indicating here the impossibility for a perpetrator of a heinous crime (be it the former Chilean dictator Pinochet or the former Nazi interrogator Klaus Barbie) to 
presume to have the moral authority to insist on a public forgetting of those crimes. This desire to forget the past where a mass crime has been committed runs contrary to the fact that there exists a large number of witnesses. In his critique of the historiographical reduction of memory, Paul Ricoeur reiterates memory’s importance:

History can expand, complete, correct, even refute the testimony of memory regarding the past; it cannot abolish it. Why? Because, it seemed to us, memory remains the guardian of the ultimate dialectic constitutive of the pastness of the past, ... which designates its original and, in this sense, indestructible character. That something did actually happen, ... In this regard, events like the Holocaust and the great crimes of the twentieth century, ...stand in the name of all the events that have left their traumatic imprint on hearts and bodies: they protest that they were and as such they demand being said, recounted, understood. This protestation, which nourishes attestation, is part of belief: it can be contested but not refuted. (Memory, History, Forgetting 498)

No matter how much distance is placed between us and events like "the great crimes of the twentieth century," there will always be the attestation that "something did actually happen.” Memory may be challenged but it cannot be eradicated - such is the nature of testimony that is passed down through the generations and haunts the collective consciousness. To Ricoeur, the issue of testimony and the responsibility of giving an account of the past is a matter that is of considerable importance. In an interview published in 2005, he posits four abilities of "capable man”: the ability to speak, the ability to act, the ability to narrate, the ability to be accountable ("Memory, History, Forgiveness: A Dialogue” 18-19). Ricoeur describes the ability to narrate as being the prerequisite to the ability to be accountable, where being accountable is considered a duty (19). This duty of accountability for humankind is further rooted in the concept of testimony, an oral tradition of bearing witness that is eventually preserved in document form (Memory, History, Forgetting 316). Testimony preserves the "trace" of past activity, and it is testimony that does not allow for crimes on a 
massive scale to be forgotten. In his discussion of the links between memory and justice in Memory, History, Forgetting, Ricoeur speaks of a debt that is not limited to the concept of guilt. It is a debt we each have "to those who have gone before us for part of what we are.”

The duty of memory is not restricted to preserving the material trace, ... but maintains the feeling of being obligated with respect to these others, of whom we shall later say, not that they are no more, but that they were. (89)

As individuals we are all inextricably linked to one another through our influences on each other, and fulfilling the duty to remember those whose lives have influenced us is to acknowledge that interconnectedness of our lives, the fact that we all exist and that our existence depends on those who have gone on before us in time. The public might wish to forget and deny the existence of the clones in Never Let Me Go, but their expired lives bear testimony through the collective memories of the clones who are alive of the horrific nature of their short existence in service to humankind. The narrative represents Kathy’s attempts, in John Mullan’s words, to “make a story of herself and others who might be like her” (113). Even the organs inherited by the humans for their very preservation also bear traces of the clones’ existence.

The world of Hailsham that the clones leave behind represents the tranquility and innocence of their youth, and throughout the novel the narrative is tinted with the memories of Hailsham; these memories stem not only from Kathy but from all of Hailsham's former students. Never Let Me Go is a novel that is both sad and elegiac, with a narrative that is tinged with nostalgia. Kathy's recollections of Hailsham often begin with happy memories of childhood innocence, but as that memory links up with 
other memories, her recollections eventually reach a sad or unhappy conclusion, signaling an end to her childhood innocence. These memories of Hailsham serve as a bond between the school and its former students; a memory of a happier life and a more privileged upbringing than most other clones in the country have experienced. During her time as a carer, Kathy chances upon a former Hailsham schoolmate named Laura in a car park at a service station. Laura has also become a carer, but it becomes obvious to Kathy that she is finding great mental and emotional difficulty with the job. Laura eventually brings up Hailsham, saying how "weird” it all is that Hailsham is closing down, and the two have a brief but intimate exchange about their former school. This exchange comes as a huge relief to the both of them:

It was that exchange, when we finally mentioned the closing of Hailsham, that suddenly brought us close again, and we hugged, quite spontaneously, not so much to comfort one another, but as a way of affirming Hailsham, the fact that it was still there in both our memories. [Italics mine] (Ishiguro, Never Let Me Go 193)

Kathy and Laura are both aware of the rumors of the closing down of Hailsham that have been traveling around the country. The most important thing for both of them (and for all the former Hailsham students) is that Hailsham remains with them in the form of memories, both individual and shared. Being able to share the memories and feelings of their days in Hailsham is a way of "affirming” its existence as an integral part of their personal histories (193). This collective affirmation of Hailsham among the former students translates itself into an act of mourning whereby the school becomes the lost object. The act of mourning has been described by Freud as a "reaction to the loss of someone who is loved," and that there is an inability to adopt any new object of affection that would replace the old one (252). The reason for this inability is the fear of forgetting or losing the memory of the loved object. In many 
ways, reaffirming shared memories is more real to the parties involved than the continued existence of the object of their memories, for it is the shared memories that bind them to that object, and they affirm their identities through their allegiances to it. In Regimes of Memory, Susannah Radstone and Katharine Hodgkin indicate that one of the inherent difficulties concerning memory is in trying to bridge the "gap" between the private and the public elements of memory - the individual's relation to "the social” (3). Ricoeur suggests a solution to this "gap" when he discusses an intermediate level of reference between individual and collective memory: the level of our “close relations” (Memory, History, Forgetting 131-32). Ricoeur describes close relations as people to whom we attribute a distinct kind of memory; they are "people who count for us and for whom we count," and being "privileged others” they are situated at varying points in the gap between the self and others. It is our close relations who approve of our existence, and in reciprocity we approve of theirs (132). This concept of the relationship between us and our close relations is a profound one, and the clones' memories of Hailsham remain active as a result of the close friendships that are formed within that community. The close friendships (or relations) allow for what Ricoeur terms "concrete exchanges" (131) between the living memories of Kathy, Ruth, and Tommy, and the collective memory of the community that came from Hailsham.

In Ishiguro’s writing, dream or dream-like episodes frequently appear and often serve as vivid metaphors for loss and repression. One instance of this is a vivid image that Kathy has from walking behind a man dressed up as a clown carrying a bunch of about twelve helium balloons, each with a face and shaped ears. Hearing about the closing down of Hailsham from an old schoolmate earlier that day, Kathy 
finds herself going back to that vivid image of the man and the balloons again. To her, the closing of Hailsham is similar to the cutting of the strings attached to the balloons that were held in the man's hand. Once the strings are cut, the individual balloons will have "no real sense" in which they "belonged with each other" any more; Kathy adds that it is "unnerving" to think that things back at Hailsham are no longer carrying on “just as always” (Never Let Me Go 194-95). Following these thoughts, and the chance meeting with Laura in her car, Kathy realizes that time is indeed running out for all of them and these events become the final push that compels Kathy to make arrangements to be Ruth's carer. The initiating of this plan of action not only leads to Kathy meeting up with Ruth after so many years, but leads to Kathy being reunited with Tommy as well. Later on, when the three of them are reunited by a trip to go see a beached boat mysteriously located in some open marshland, Ruth recounts a recent dream she had related to the closing down of Hailsham. She dreamt that she was in one of the rooms at Hailsham looking out of the window. The space outside was so badly flooded it resembled a "giant lake” and all manner of "rubbish” floated by her window (205). The strange thing about the dream is the tranquil and positive mood Ruth experienced despite her being aware that Hailsham had closed down. The peace and tranquility Ruth experiences in her dream, whilst being located in one of the old buildings she is familiar with from her school days, reflect the idyllic innocence of her time at Hailsham. These dream-like experiences bring about two different yet poignant reminders of what it means for these former students to know that Hailsham will no longer be in existence in the real world. Hailsham represents not only their childhood innocence but is also a site of memory that imbues their lives with a sense of collective identity. 
The experience of mourning the loss of a place through the act of remembering comes in several guises in the narrative. Like The Remains of the Day, Never Let Me Go is a novel whose narrative momentum is carried along by the motifs of traveling and motoring. Both protagonists travel in cars and the journeys and accompanying scenery of England provide the backdrops for their recollections. On two separate occasions, Kathy has only a brief moment with which to remember Hailsham before driving off for somewhere else. The first instance is in the chance encounter with Laura in the car park of the service station described earlier. This brief moment of intimacy, after their not having seen each other for so many years, symbolizes their mutual affirmation of Hailsham's existence in their memories. The second episode, taking place at the very end of the novel, sees Kathy in a reminiscent mood as she ponders all the people and things that she has lost, including Tommy, Ruth, and Hailsham. As she pays tribute to these different parts of her life, she allows her imagination to run free and celebrates her memory of them while at the same time mourning the loss of not having them in her life anymore. This intensely sad episode, one of the most transcendent moments in the novel, does not last for long as a short while later Kathy turns back to her car to "drive off to wherever it was [she] was supposed to be” (Ishiguro, Never Let Me Go 263). Acting as tributes to the memory of Hailsham, these brief moments of remembrance affirm its continued existence in her heart and mind in the midst of her exhausting work schedule as a carer. These tributes to Hailsham and its community take place over short bursts of time; but in a world where Kathy has to be rushing from one recovery centre to another, they are her only source for reconnecting with her past and with Hailsham, and for paying tribute to and reaffirming its ongoing memory in her life as it begins to draw to a close. In The Collective Memory, Maurice Halbwachs suggests that collective memories of the past 
are only kept in the consciousness of individuals from the social group who are still living and who keep the memories alive (80). Halbwachs posits that if human life were to be shorter, a group’s collective memory covering a shorter time frame would "never grow impoverished" as tradition would not hinder change and evolution within that group (82). Collective memory within a group is constantly changing as the older members die and newer members bring in new memories, and it is always difficult to tell when a collective memory has disappeared. In the case of the clones with their shorter life expectancy, their collective memory of Hailsham becomes all the more intense and richer, and each new generation of clones will bring in new memories to the group, creating a "palimpsest of memories” (Walkowitz 127) of Hailsham, until the school is closed down and the collective memory of Hailsham slowly begins to disappear. These memories of Hailsham are not only precious to the school's former students. Oddly enough, they are also important to other donors who are not from Hailsham but who appropriate these memories as a source of comfort for themselves. At the beginning of the novel, Kathy cites one donor in particular who makes repeated requests for descriptions of life at Hailsham so he may imagine these images to be a part of his own history (Ishiguro, Never Let Me Go 5). Because the idea of Hailsham, and its more humane development of the clones, becomes a source of positivity that the clones want to have in their minds in place of the horrific conditions in which they grew up, they do not mind appropriating the memories of other clones as their own.

\section{Never Letting Go of Memories}


Kathy's repressed feelings are frequently revealed through her recollections. Her time as a carer is coming to an end at the end of the year, and the expectant slowing down in her pace of life has given her the desire to “order” her memories:

I'm sure it's ... to do with preparing for the change of pace, that I've been getting this urge to order all these old memories. What I really wanted, I suppose, was to get straight all the things that happened between me and Tommy and Ruth after we grew up and left Hailsham. ... I realize now just how much of what occurred later came out of our time at Hailsham, and that's why I want first to go over these earlier memories quite carefully. (Never Let Me Go 34)

There does not seem to be a strong sense of regret at the way life has turned out for the protagonist that is evident in Ishiguro's earlier works. These recollections appear to be the thoughts of an individual who is taking stock of all that has happened and is attempting to understand the connectedness of past events. It is the understanding of the narrative formed by these memories that becomes the key to understanding the past. Though Ricoeur describes narrative as the path of mourning a shared loss, he is not implying that the person who is in mourning is to tell his or her story from his or her own perspective, as that would be counter-productive. He is implying, rather, that the person must "know how to tell one’s own story as seen by others," for the person to let himself or herself "be narrated by the other" ("Memory, History, Forgiveness: A Dialogue” 24). Kathy has to remove herself from the subjectivity of her inner thoughts and allow herself the chance to tell her life story from the perspective of "the other." This desire to go over her memories "quite carefully" demonstrates the intricacies of self-analysis that are involved in the reconstruction of the narrative of old memories. As the three friends become reunited again, these attempts by Kathy to piece together her old memories are tested by her interaction with both Ruth and Tommy. 
The foreshortened life-span of a clone determines that time is made even more precious. In creating Kathy, Ruth, and Tommy, Ishiguro depicts lives that mirror our own in many ways, but with the general exception of a shorter time frame. The human desire for wholeness and meaning is a desire that these clones experience as well. Like us, they desire happiness and relationships, and have a need to be included as part of a community. Hailsham provided for them in these areas during their formative years, but they soon discover that the world outside of Hailsham is much more reluctant to accept them. In the epilogue to Memory, History, Forgetting, Ricoeur theorizes on "The Forgiveness Equation” and the concept of “The Fault.” The link between the act and the agent in relation to a fault is mediated through a reflecting memory. It is through this reflection that the feeling of a loss of wholeness is revealed, the desire for wholeness being one that comes from deep within the ego (462). This desire for wholeness, however, can also be described as a desire to find meaning in one's life. Describing the constant human need to mark "transitional moments” in history, Frank Kermode suggests that this comes about from a need to "make sense of our worlds and our lives" as people who are always "stranded in the middle” of time, between a beginning and an end:

... we need fictions of beginnings and fictions of ends, fictions which unite beginning and end and endow the interval between them with meaning. (190)

Because we are always "stranded in the middle" of time as individuals and as communities, we will always harbour the deepest human need for meaning (or relevance) to our lives; we have a desire to find where we are in time, and what our larger significance to that particular period of time is. Ricoeur puts this idea into 
perspective in an exchange concerning the differences between microhistory and macrohistory. In microhistory there occur situations of uncertainty involving individuals who have "a closed horizon" and "attempt to orient themselves” within a particularly significant moment in history; in the larger-scale view of macrohistory, however, only the developing forces are seen, and not the plight of individuals (“Memory, History, Forgiveness: A Dialogue” 13). In Never Let Me Go, the national and global imperative to mass produce and cultivate clones for the purposes of harvesting organs overshadows the horrific fate awaiting each clone and the ethical considerations surrounding their very existence. When we take into account the foreshortened lifespan of the clones, the impulse for them to find out the meaning of their existence takes on a greater intensity of purpose. Unlike the clones, many of us have the possibility open to our making restitution for our past errors and finding new directions in which to take our lives. Our actions are a consequence of our past experiences, and time often gives us the opportunities to build on those experiences and make decisions accordingly. With an average lifespan of about thirty years, the clones, on the other hand, are deprived of these options. They do not have the opportunity to experience some sense of a personal history and the maturing of thought and perception that comes with age. The clones seem to have only two choices: to be resigned to their fates and await their deaths, or to experience the fullness of life as much as they can with the little time that they have. The clones in Margaret Atwood's Oryx and Crake, by contrast, are genetically more perfect than humans and despite their innocence and naïveté have an aura of menace about them as they gain in knowledge and understanding. Ishiguro’s clones do not pose such a threat to humankind, and appear to be as passive as Masuji Ono from An Artist of the Floating World or Stevens from The Remains of the Day in their resignation to their 
duties and their fate. In Never Let Me Go, the small number of those privileged enough to have been raised in the protective environment of Hailsham realize very quickly that the world outside is a lot more unkind, and this realization makes them cling even harder to their memories of Hailsham. One of the ethical controversies surrounding Hailsham, indeed, is whether such institutions that provide a nurturing environment for the clones are ultimately doing more harm than good by sheltering them in a bubble when they are growing up, and giving them a false impression of life before releasing them into the wider world to face their harsh realities as organ donors. The guardians at Hailsham have kept the students in a protective environment and unaware of the circumstances surrounding their existence. Tommy certainly questions those methods when the truth about Hailsham and cloning is revealed to him and Kathy when they meet the former head guardian Miss Emily again (Never Let Me Go 250). ${ }^{2}$

Never Let Me Go marks a step away from the preoccupations of Ishiguro’s earlier work with regard to the themes of memory and forgetting. Instead of the protagonist's desire to let go of the past and to move on with life, Ishiguro presents us with a novel that focuses on the desire never to forget, a novel about the continual affirmation of the memory of people and places that have made us who we are. Ishiguro has imbued the novel with a sense of nostalgia for a missing childhood that he himself has experienced when his family never returned to Nagasaki, despite initially planning to be in England for only a short time. Ishiguro has admitted that part of his desire to write stems from feeling the need to preserve his childhood memories through his writing (Hegarty 14). The act of remembering Hailsham serves as a tribute and affirmation of its existence in the hearts and minds of its former 
students. These memories for them are happy, carefree memories of a time in their lives where the future was a blissful and distant thought. Memories are intensely personal; Ricoeur considers memory to be "radically singular," and an individual's memory represents his or her unique past (Memory, History, Forgetting 96). These memories are the clones' only real possessions, for even their own bodies do not belong to them; their lives must "run the course that's been set for [them]" (Ishiguro, Never Let Me Go 243).

In the novel, memories often refer to a past that has been fragmented through the passage of time. Such memories are frequently described as lost items or "strange rubbish” (263). But there is a link between memory and personal objects. That is a theme Ishiguro raises in his preceding novel When We Were Orphans, when the protagonist Christopher Banks tells his ward Jennifer about the importance of personal "things," especially things that have a link to the past for orphans like the both of them. When news arrives that Jennifer's trunk containing all her possessions that was on its way over from Canada is lost at sea, Jennifer reacts rather calmly to the bad news. She says to Banks that once someone has lost something as monumental as one's parents, it is simply not possible to care about the loss of mere personal possessions or "things" (132). Banks disagrees, however, and replies that these “things” are important, and that he knows they are important because he had been in a predicament similar to hers when he came to England after losing his parents. He had a trunk that contained personal possessions special to him, and that he would have been upset if they had got lost. These "things" or possessions carry more value and meaning beyond their face value as objects; they carry with them the memories and histories of a life that has disappeared. They link an individual to his or her past and 
have an uncanny way of uniquely preserving that past through memory. In When We Were Orphans, they carry with them the memories of the orphan's childhood, of a time when a family and a home still existed. In the third volume of Time and Narrative, Ricoeur describes a crucial element within the workings of tradition:

It signifies that the temporal distance separating us from the past is not a dead interval but a transmission that is generative of meaning. (221)

The narrative space missing between childhood and the present is indicative of this temporal distance; it is not an empty space, but one that is imbued with meaning through the events in the past that have happened and that are still in some form of communication with events in the present. These lost items become a link between the individual and the past and uniquely preserve that past in memory. In Never Let Me Go, one instance of the strange “rubbish” of memories is Ruth's dream of a flooded Hailsham that we examined earlier involving items of rubbish floating on the water (205). A second such instance occurs at the close of the novel, partly described earlier. Here, Ishiguro presents us with a most affecting representation of lost memory. Kathy tells of a very late episode when she drove up to Norfolk, a place that Hailsham students were told was the "lost corner" of England, where lost items ended up, and is also the place to which the reunited trio of Kathy, Tommy, and Ruth had gone on a recent adventure (263). The episode of which Kathy speaks takes place a couple of weeks after Tommy has died from his final organ donation. Kathy stops her car where she spots a cluster of trees in the midst of an endless vista of flat fields. She stands before acres of ploughed earth surrounded by a barbed wire fence, and notices "all sorts of rubbish" that have been blown by the winds and have been caught on the barbed wire. It is at this point that she allows herself to imagine that everything she 
has lost since her childhood has been washed up on that spot, and that if she waits long enough, Tommy will eventually appear and wave to her. Kathy’s memory comes alive through her imagination, but she never allows this moment of fantasy to carry her away, and part of her knows that Tommy will never come back to her in this life. Told in Ishiguro's deftly controlled prose, this achingly poignant scene provides a very apt visual representation of childhood memory; many memories have been lost and the former students of Hailsham are often subconsciously looking for these memories and perhaps even yearning for them. Such a statement on memory highlights a universal desire to reminisce and reclaim moments from our past that have been lost, particularly from our childhood; and perhaps this search for lost childhood and the desire to reaffirm its memories are what compel Ishiguro to find new ways of preserving his own childhood memories through his fiction.

The importance the clones place on memory in Never Let Me Go bears resemblance to the importance placed on memory by the orphans in When We Were Orphans. The desire for a happy and peaceful memory is common to the three orphans depicted in the earlier novel. This desire forms an intangible link between Christopher Banks, his ward Jennifer, and Sarah Hemmings as they seek out their hidden pasts and "the shadows of vanished parents," the three of them longing for "something that will just be there, always, like tomorrow's sky" (When We Were Orphans 313). Ricoeur describes a happy memory as the desired outcome of the spirit of forgiveness's mediation of the past. Happy memory does not intend to forget the past and its evils, but speaks rather of the past without resentment and anger (“Memory, History, Forgiveness: A Dialogue” 11, 24). The desire for a happy and peaceful memory forms a common ground between these three characters in When We 
Were Orphans, and we observe a similar dynamic with the clones in Never Let Me Go. The desire of the latter for a carefree memory of their time at Hailsham demonstrates a longing for stability and belonging that their horrific fate denies them. Their resignation regarding their fate belies how fiercely protective they are of their memories. Their memories represent the only part of themselves that cannot be taken away by humankind.

Ricoeur posits the idea of happy memory as the link between memory, history, forgetting, and forgiveness (Memory, History, Forgetting 493-94), suggesting that if there exists the concept of a happy memory, there also exists the possibility of a happy forgetting (501). He describes a profound forgetting he calls "the reserve of forgetting," or a "carefree” forgetting. The reserve of forgetting recognizes "the unperceived character of the perseverance of memories" (428), and how the act of forgetting indicates "their removal from the vigilance of consciousness" (440). The reserve of forgetting recognizes the pervasive nature of memories, and the consequence of a happy (or peaceful) memory that speaks of the past without anger is a reconciliation that does not deny the past nor is resentful of it, allowing the memories to persevere in the unconscious away from immediate perception. Citing Søren Kierkegaard's extolling of forgetting as "the liberation of care," and the Book of Matthew's exhortation in the Bible to "consider the lilies of the field and the birds of the air," Ricoeur synthesizes these ideas with the concept of the reserve of forgetting, one that exhibits elements of “insouciance” and “carefreeness” (504-05). The reserve of forgetting is an "idle" kind of forgetting that is not work. It allows for memories to linger and never to fade into oblivion. This is how the clones reaffirm, both individually and collectively, the memories of the people and the places that 
mean everything to them. Their memorialization of Hailsham and of their times together is accomplished through a carefree forgetting that is profoundly and poignantly linked with the concept of a happy or peaceful memory. Kathy’s memories of Hailsham, and her more recent memories of Tommy, will affirm the existence of these people and places in her heart and in her mind. Cynthia Wong suggests that the ending to Never Let Me Go expresses "a mature bereavement and a push to move through an insufferable situation,” unlike Ishiguro’s earlier novels that exhibit a protagonist's “futile spirit” (83). The endings to Ishiguro’s novels have almost always been distinctly characterized by a "very sad peal” that signifies the closing or ending of the lives of the novels' protagonists (85). But Wong notes that both When We Were Orphans and Never Let Me Go end with the protagonists nearing a physical death that is "marked by spiritual hope” (86). Kathy’s longing for her past to return to her, and her wish to be reunited with Tommy, represent a painful yearning but also offer a strange sense of hope that brings a spiritual element to the novel's final moments. Despite the sense of unease we feel at Kathy's perceived optimism in the face of death, there is waiting for her in the near future a time to which to look forward. With her life gradually slowing down in the coming months as she prepares to become a donor, Kathy hopes to have the time to organize her memories, and allow the work of mourning and the process of a carefree forgetting to imbue the remainder of her short life with a profound happy memory and peace. Ishiguro's novel, in its depiction of the plight of Kathy, Ruth, and Tommy, becomes a fitting eulogy for Hailsham and its former students, and a way for us as readers to always remember them.

\section{University of Sussex}




\section{Brighton, UK}

\section{WORKS CITED}

Atwood, Margaret. Oryx and Crake. London: Bloomsbury, 2003.

Freud, Sigmund. "Mourning and Melancholia." On Metapsychology: The Theory of Psychoanalysis. Trans. James Strachey. Ed. Angela Richards. 1984. London: Penguin, 1991. 245-68.

Halbwachs, Maurice. The Collective Memory. 1950. Trans. Francis J. Ditter, Jr. and Vida Yazdi Ditter. New York: Harper and Row, 1980.

Hegarty, Shane. “An Artist of Alternative Worlds.” Irish Times 11 Mar. 2005: 14.

Ishiguro, Kazuo. An Artist of the Floating World. 1986. London: Faber, 1987.

---. “Interview with Kazuo Ishiguro.” Interview by Karen Grigsby Bates in May 2005. Conversations with Kazuo Ishiguro. Ed. Brian W. Shaffer and Cynthia F. Wong. Jackson: UP of Mississippi, 2008. 199-203.

---. Never Let Me Go. London: Faber, 2005.

---. The Remains of the Day. 1989. London: Faber, 1990.

---. When We Were Orphans. 2000. London: Faber, 2001.

Kermode, Frank. The Sense of an Ending: Studies in the Theory of Fiction with a New Epilogue. New York and Oxford: Oxford UP, 2000.

Mullan, John. “On First Reading Kazuo Ishiguro’s Never Let Me Go.” Kazuo Ishiguro: Contemporary Critical Perspectives. Ed. Sean Matthews and Sebastian Groes. London and New York: Continuum, 2009. 104-13.

Night and Fog (Nuit et brouillard). Dir. Alain Resnais. Writer Jean Cayrol. Perf. Michel Bouquet. Argos Films, 1955.

Radstone, Susannah and Katharine Hodgkin. "Regimes of memory: an introduction.” Regimes of Memory. Ed. Susannah Radstone and Katharine Hodgkin. 2003. Digital printing edition London: Routledge, 2005. 1-22.

Ricoeur, Paul. Memory, History, Forgetting. Trans. Kathleen Blamey and David Pellauer. Chicago: U of Chicago P, 2004.

---. "Memory, History, Forgiveness: A Dialogue Between Paul Ricoeur and Sorin Antohi." Interview by Sorin Antohi. Trans. and annotated by Gil Anidjar. Janus Head 8.1 (Summer 2005): 8-25. This interview can also be downloaded from the journal's website. 3 Jan. $2012<$ http://www.janushead.org/8-1/Ricoeur.pdf>.

---. Time and Narrative. Trans. Kathleen Blamey and David Pellauer. Vol. 3. 1988. Chicago: U of Chicago P, 1990. 
Sandhu, Sukhdev. “The Hiding Place.” Daily Telegraph 26 Feb. 2005, Books: 1-2.

Suleiman, Susan Rubin. Crises of Memory and the Second World War. Cambridge, Massachusetts: Harvard UP, 2006.

Sutcliffe, William. "History Happens Elsewhere.” Rev. of When We Were Orphans, by Kazuo Ishiguro. Independent on Sunday 2 Apr. 2000, Sunday Review: 49.

Walkowitz, Rebecca L. Cosmopolitan Style: Modernism Beyond the Nation. New York: Columbia UP, 2006.

Wong, Cynthia F. Kazuo Ishiguro. 2nd ed. Devon: Northcote House, 2005.

\section{ABOUT THE AUTHOR}

Yugin Teo teaches literature and film at the University of Sussex and the University of Brighton. He completed his doctorate on Kazuo Ishiguro's fiction at the University of Sussex and his monograph on Ishiguro's writing and memory is due to be published by Palgrave Macmillan in 2014. He has published his own poetry and short fiction in The Frogmore Papers and elsewhere. 


\section{NOTES}

${ }^{1}$ The shadow of the Second World War is never far away in many of Ishiguro's novels. William Sutcliffe, in his review for When We Were Orphans, suggests that even when he is writing about something seemingly unrelated, his writing is often "infused with a profound sense of the effect that great historical events have” on the lives of individuals (49). The war is used in Never Let Me Go as part of a premise for an alternate future set in England. Speaking to Sukhdev Sandhu, Ishiguro said that his preference was for his novels to be read metaphorically for their general themes, rather than being read as realist historical fictions (Sandhu 1-2). He is a reluctant writer of the war, but the oblique and indirect way that the war operates in his fiction makes his work effective in dealing with this theme.

${ }^{2}$ Ishiguro's experience of being a parent may have had a strong influence on his writing for this novel. He has stated that one of the themes he wants to explore in writing the novel is how the life of a child is protected by the family and kept in a kind of protective bubble, giving the impression that the world is a better and nicer place than it really is ("Interview" 199). 